\title{
Illness-induced taste aversion under states of deprivation and satiation
}

\author{
JACK H. PECK and ROBERT ADER \\ University of Rochester School of Medicine and Dentistry \\ Rochester, New York 14642
}

\begin{abstract}
A taste aversion to saccharin was induced under conditions of satiation or deprivation. Subsequent testing occurred under the same or opposite conditions. A preference test vielded significant drug-placebo effects only under similar training and testing conditions. Ss trained and tested under satiation produced the greatest drug-placebo differences. The data are discussed in terms of state dependency and the procedures used to induce and measure the taste aversion.
\end{abstract}

The illness-induced taste aversion paradigm (Garcia, Ervin, \& Koelling, 1966: Garcia, McGowan, Ervin, \& Koelling, 1968) has stimulated a great deal of research in a relatively short period of time. As is the case with any new exciting phenomenon, studies and applications reflecting specialized interests frequently precede parametric and methodological experiments. Some obvious exceptions are the parametric studies on the nature of the CS (Dragoin, 1971; Etscorn, 1973) the US (Dragoin, 1971: Garcia, Ervin, \& Koelling, 1967; Revusky, 1968), and the CS-US interval (Kalat \& Rozin, 1971; Nachman, 1970; Revusky, 1968; Smith \& Roll, 1967). Dragoin, McCleary, and McCleary (1971) compared the forced-choice and preference procedures for evaluating conditioned taste aversions and found the latter to be the more sensitive of the two. In the present study, the consumption of a highly palatable novel solution was followed by treatment with a toxic agent. Subsequently, the animal was given a choice between the novel solution and plain water.

The role of ingestive behavior in taste aversion learning was studied by Domjan and Wilson (1972). In one experiment curare was used to eliminate ingestion, and it was found that tasting without ingesting the distinctively flavored CS attenuated the illness-induced taste aversion. In other studies the amount of fluid consumed was manipulated by training deprived and satiated animals. For the "satiated" Ss, presentation of the distinctively flavored CS and the toxic US occurred after the animals had consumed their daily allotment of water. All animals were subsequently tested under conditions of deprivation. Deprived animals, which consumed the greater volume of novel solution during training, developed a stronger taste aversion than the previously satiated animals.

The state of the animal was examined more extensively in the present study. Since an approach to and the consumption of a novel solution that is followed by gastrointestinal upset are not necessary conditions for establishing a taste aversion, we designed the present study to determine the effects of deprivation and satiation during training and testing on illness-induced avoidance behavior.

\section{METHOD}

The Ss were 96 experimentally naive Charles River (CD) rats, 90-120 days old. They were maintained under ad lib food and water conditions, constant temperature $\left(72^{\circ} \mathrm{F} \pm 2^{\circ} \mathrm{F}\right)$, and a 12 -h light-dark cycle (light from 5:00 a.m. to 5:00 p.m.). A proportionate number of male and female Ss were randomly assigned to groups in a 2 (deprived or satiated, i.e., nondeprived during training) by 2 (deprived or satiated during testing) by 2 (drug or placebo) factorial design.

Four days before training the animals were individually caged, and $24 \mathrm{~h}$ before training water was removed from those Ss to be trained under the deprivation condition. All Ss were weighed at this time. During training each $S$ received five drops (approximately $.1-.2 \mathrm{ml}$ ) of a $.1 \%$ saccharin solution from an eyedropper placed just inside the animal's mouth. This was followed immediately by an intraperitoneal injection of either cyclophosphamide $(50 \mathrm{mg} / \mathrm{kg}, .1 \mathrm{ml} / 100 \mathrm{~g}$ body weight) or a vehicle placebo (25\% ethanol) which does not, in the volumes injected, induce an aversion to the distinctively flavored CS (Ader, 1973). During the following 48-h recovery period, all Ss were supplied with plain water ad lib.

Two days after training, the drinking water was taken away from the animals to be deprived during testing, and $24 \mathrm{~h}$ later all animals were given a two-bottle preference test between water and $.1 \%$ saccharin. Water and saccharin intake were determined at $2.5,5.0$, and $24.0 \mathrm{~h}$ by weighing the bottles. Previous (unpublished) research disclosed that these conditioning parameters induce a taste aversion that is highly resistant to extinction when animals are given brief extinction trials at 3-day intervals. However, most rats, even when poisoned, develop a subsequent preference for saccharin if they are exposed to it continuously for $24 \mathrm{~h}$. The 2.5 - and 5-h samples were chosen to measure the development of this preference.

\section{RESULTS}

Figure 1 shows the percentage intake of saccharin for drug and placebo animals under deprived and nondeprived conditions during training and testing. Separate analyses of variance were applied to the data obtained at $2.5,5$, and $24 \mathrm{~h}$. Each analysis yielded a significant three-way interaction $(F=181,84$, and 53 , respectively; $\mathrm{df}=1 / 88 ; \mathrm{p}<.01$ in all instances). There were no significant effects above the three-way interactions. As can be seen in Fig. 1, similar conditions of deprivation or satiation during training and testing led to significant drug-placebo differences; the cyclophosphamide-treated animals showed a distinct 


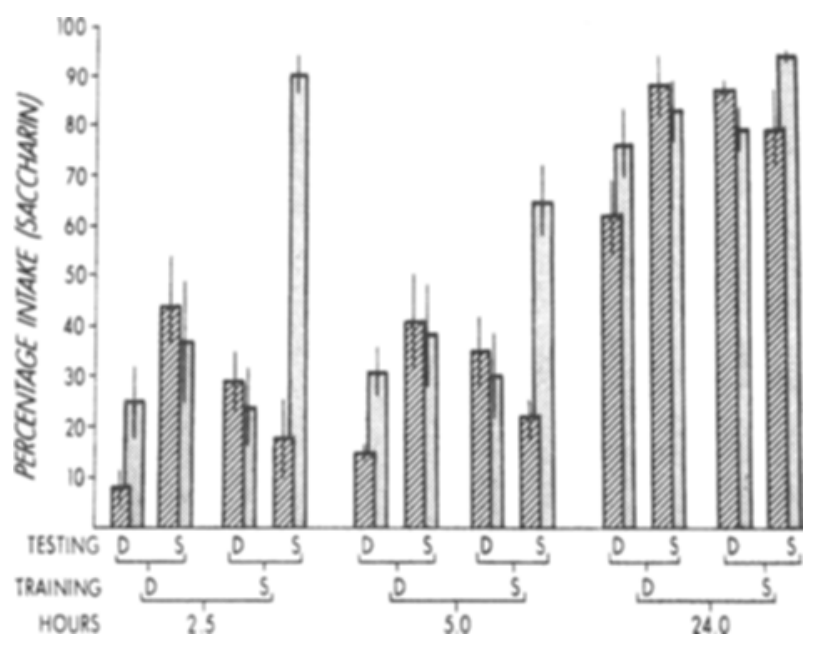

Fig. 1. Percentage intake of saccharin solution (mean $\pm \mathrm{SE}$ ) in cyclophosphamide- (hatched bars) and placebo-treated rats under conditions of deprivation (D) and satiation (S). Cumulative fluid intake was measured $2.5,5$, and $24 \mathrm{~h}$ after the simul taneous presentation of saccharin and plain water.

aversion to the CS, which is reflected in their reduced preference for the saccharin solution at each of the sample times. In contrast, switching to or from a deprived state resulted in nonsignificant differences between the drug and placebo groups.

The absolute volume of saccharin solution and plain water consumed is given in Table 1 . The Ss deprived on the day of testing had a larger total fluid intake over the first $5 \mathrm{~h}$ than nondeprived Ss, but this difference was virtually eliminated by $24 \mathrm{~h}$. With the exception of the placebo-treated Ss trained and tested under conditions of satiation, these data show that even nonpoisoned animals require some time to develop a distinct preference for sweet water. Moreover, pairing the novel saccharin solution with gastrointestinal upset impedes that development despite the experimentally manipulated differences in the absolute volume of fluid consumed. The percentage data plotted in Fig. 1, then, are an appropriate reflection of the conditioned taste aversion or preference of the differentially treated animals. Another interesting feature of the data revealed by the absolute levels of fluid intake is that placebo-treated animals tested when deprived show an initial neophobia to the novel CS that is not apparent when such animals are tested while satiated.

\section{DISCUSSION}

Given these CS and US parameters, three points can be made from the present data: (1) The production of a successful taste aversion does not require conditions of deprivation. (2) The only significant taste aversions occurred under similar training and testing conditions. (3) There was a greater aversion in satiated than in deprived animals.

The data reported by Domjan and Wilson (1972) provide partial support for some of these findings. Although their animals were satiated only in the sense that the CS and US were administered after the daily allotment of water, the Ss they trained under "satiated" conditions and tested under deprived conditions did display a taste aversion. However, these animals showed weaker aversions to the novel solution than animals trained and tested under conditions of deprivation. Domjan and Wilson attributed this difference to the smaller intake of distinctive fluid by the satiated animals on the training day. Increasing the volume of CS ingested by the nondeprived Ss eliminated differences in subsequent preference behavior. A contrasting finding is our observation of a conditioned taste aversion only in animals trained and tested under constant conditions of deprivation or satiation. No differences between drug and placebo groups were observed when Ss were deprived during training and satiated during testing or when Ss were satiated during training and deprived during testing, the latter being the conditions which most closely approximated the procedure used in the Domjan and Wilson study. In view of the direct relationship between the concentration of the CS and the magnitude of the conditioned taste aversion (Dragoin, 1971), it should be noted that Ss in the present experiment were subjected to half the

Table 1

Absolute Cumulative Intake of Saccharin and Plain Water (Mean \pm SE) at 2.5, 5.0, and $24.0 \mathrm{~h}$ as a Function of Deprivation and Satiation Conditions During Training and Testing

\begin{tabular}{|c|c|c|c|c|c|c|c|c|}
\hline \multirow{3}{*}{$\begin{array}{c}\text { Training } \\
\text { Condition }\end{array}$} & \multirow{3}{*}{$\begin{array}{l}\text { Treat- } \\
\text { ment }\end{array}$} & \multirow{3}{*}{$\begin{array}{c}\text { Volume } \\
(\mathrm{ml})\end{array}$} & \multicolumn{6}{|c|}{ Testing Condition } \\
\hline & & & \multicolumn{3}{|c|}{ Deprivation } & \multicolumn{3}{|c|}{ Satiation } \\
\hline & & & $2.5 \mathrm{~h}$ & $5.0 \mathrm{~h}$ & $24.0 \mathrm{~h}$ & $2.5 \mathrm{~h}$ & $5.0 \mathrm{~h}$ & $24.0 \mathrm{~h}$ \\
\hline \multirow{2}{*}{ Deprivation } & Drug & $\begin{array}{l}\text { Saccharin } \\
\text { Water }\end{array}$ & $\begin{array}{r}1.8 \pm .6 \\
18.6 \pm 1.3\end{array}$ & $\begin{array}{r}3.1 \pm 1.0 \\
21.3 \pm 1.6\end{array}$ & $\begin{array}{l}77.3 \pm 17.1 \\
34.3 \pm 3.9\end{array}$ & $\begin{array}{l}3.0 \pm 1.1 \\
1.8 \pm .3\end{array}$ & $\begin{array}{l}4.9 \pm 2.2 \\
3.0 \pm .3\end{array}$ & $\begin{array}{r}115.1 \pm 21.2 \\
8.0 \pm 2.3\end{array}$ \\
\hline & Placebo & $\begin{array}{l}\text { Saccharin } \\
\text { Water }\end{array}$ & $\begin{array}{r}6.8 \pm 1.8 \\
18.6 \pm 1.7\end{array}$ & $\begin{array}{r}9.2 \pm 1.7 \\
20.9 \pm 1.8\end{array}$ & $\begin{array}{r}125.8 \pm 19.7 \\
28.2 \pm 4.5\end{array}$ & $\begin{array}{l}2.8 \pm 1.2 \\
2.3 \pm .5\end{array}$ & $\begin{array}{l}3.8 \pm 1.4 \\
3.4 \pm \quad .6\end{array}$ & $\begin{array}{r}109.4 \pm 18.1 \\
17.1 \pm 7.1\end{array}$ \\
\hline \multirow{2}{*}{ Satiation } & Drug & $\begin{array}{l}\text { Saccharin } \\
\text { Water }\end{array}$ & $\begin{array}{r}7.4 \pm 1.9 \\
15.6 \pm 1.4\end{array}$ & $\begin{array}{l}10.4 \pm 2.5 \\
16.3 \pm 1.4\end{array}$ & $\begin{array}{r}153.0 \pm 18.0 \\
19.7 \pm 2.0\end{array}$ & $\begin{array}{r}.4 \pm .1 \\
1.9 \pm .4\end{array}$ & $\begin{array}{l}1.2 \pm .3 \\
3.0 \pm .5\end{array}$ & $\begin{array}{r}95.0 \pm 14.5 \\
9.9 \pm 2.3\end{array}$ \\
\hline & Placebo & $\begin{array}{l}\text { Saccharin } \\
\text { Water }\end{array}$ & $\begin{array}{r}4.9 \pm 1.8 \\
14.5 \pm 1.9\end{array}$ & $\begin{array}{r}7.7 \pm 2.4 \\
16.5 \pm 1.9\end{array}$ & $\begin{array}{r}104.1 \pm 9.6 \\
25.5 \pm 3.7\end{array}$ & $\begin{array}{r}3.9 \pm .8 \\
.5 \pm .2\end{array}$ & $\begin{array}{l}6.1 \pm 1.5 \\
2.1 \pm .3\end{array}$ & $\begin{array}{r}100.9 \pm 16.5 \\
5.0 \pm 1.1\end{array}$ \\
\hline
\end{tabular}


concentration (and a mere fraction of the volume) of novel CS solution used by Domjan and Wilson in equating their deprived and satiated animals. It may be hypothesized that the greater CS magnitude used by Domjan and Wilson acted to mask the interactions observed in the present study.

The present data can be viewed in terms of state dependency (Overton. 1968), since a conditioned taste aversion was observed only when animals were tested under the same conditions that prevailed during training. A possible explanation. then. for the failure to differentiate between the drug and placebo groups that were switched in state from training to testing is that. although the distinctive stimulus remained the same. the subject was altered. Hypothetically. the taste and or the response to the distinctively flavored CS could be different in deprived and nondeprived animals. Such a possibility would be consistent with documented changes in taste preferences as a function of deprivation state (Beck. Nash. Viernstein. \& Gordon. 1972: Capretta. 1962: Strouthes \& Navarick. 1967). Domjan and Wilson (1972) have once again provided some corroborative data in their curare experiment. While previously curarized and previously normal Ss showed a taste aversion. the curarized $S s$ showed less aversion than the normal controls. The lack of ingestive behavior on the part of the curarized animals was offered as a possible explanation of these results. An alternative hypothesis would be that the small difference observed by Domjan and Wilson as well as the lack of differences noted in the present study resulted from a change in state between training and testing on the part of the experimental animals.

The present data suggest that animals develop a stronger taste aversion when trained and tested while maintained on an ad lib drinking schedule than when trained and tested under conditions of deprivation. In attempting to understand this difference, which may only reflect a procedural artifact, one should consider the small volume of saccharin and the few seconds during training in which it was administered. As can be seen from Fig. 1, this effect results primarily from the baseline data provided by the nondrugged animals; it is the placebo group that was trained and tested while satiated that stands out from the placebo group trained and tested under conditions of deprivation. The absolute levels of fluid intake show that placebo-treated animals tested under deprivation actually display an initial neophobia to the novel saccharin solution and this is evidently being reflected in the relative preference scores of experimental and control groups trained and tested under conditions of satiation and deprivation. Another factor that may have contributed to this finding is the observation (Strouthes \& Navarick, 1967) that, when given a choice between saccharin and plain water, water-deprived rats consume more water than saccharin and nondeprived animals consume more saccharin than water.
Hypothetically, the placebo-treated nondeprived animals do not have to satisfy a drive state and may. therefore. be prepared to consume the previously tasted and highly palatable saccharin solution. In contrast, the deprived animals need to redress a physiological imbalance might lead them to first consume a safe solution (plain water) before drinking a safe but relatively novel solution. It may be further hypothesized that the reduced level of saccharin intake on the part of the animats trained and tested under different conditions may reflect a neophobic response to what amounts to a stimulus that is novel by virtue of their change in state and/or their motivation to satisfy a physiological need.

\section{REFERENCES}

Ader, R. "Strain" differences in illness-induced taste aversion. Bulletin of the Psychonomic Society. 1973, 1, 253-254.

Beck, R. C., Nash, R., Viernstein, L.. \& Gordon, L. Sucrose preferences of hungry and thirsty rats as a function of duration of stimulus presentation. Journal of Comparative \& Physiological Psychology, 1972, 78, 40-50.

Capret ta, P. J. Saccharin consumption under varied conditions of hunger drive. Journal of Comparative \& Physiological Psychology. 1962, 55, 656-660.

Domjan, M.. \& Wilson, N. Contribution of ingestive behaviors to taste aversion learning in the rat. Journal of Comparative \& Physiological Psychology, 1972, 80, 403-412.

Dragoin. $W$. B. Conditioning and extinction of taste aversions with variations in intensity of the CS and UCS in two strains of rats. Psychonomic Science, 1971, 22, 303-305.

Dragoin, W. B., McCleary, G. E., \& McCleary, P. A comparison of two methods of measuring conditioned taste aversions. Behavior Research Methods \& Instrumentation, 1971, 3, 309-310.

Etscorn, F. Effects of a preferred vs a nonpreferred CS in the establishment of a taste aversion. Physiological Psychology, 1973, 1, 5-6.

Garcia, J., Ervin, F. R., \& Koelling, R. A. Learning with prolonged delay of reinforcement. Psychonomic Science, 1966, 5, 121-122.

Garcia, J., Ervin, F. R., \& Koelling, R. A. Bait shyness: A test for toxicity with $\mathrm{N}=2$. Psychonomic Science, 1967, 7, 245-246.

Garcia, J., McGowan, B. K., Ervin, F. R., \& Koelling, R. A. Cues: Their relative effectiveness as a function of the reinforcer. Science, 1968, 160, 794-795.

Kalat, J., \& Rozin, P. Role of interference in taste aversion learning. Journal of Comparative \& Physiological Psychology, $1971,77,53-58$.

Nachman, M. Learned taste and temperature aversions due to lithium chloride sickness after temporal delays. Journal of Comparative \& Physiological Psychology, 1970, 73, 22-30.

Overton, D. A. Dissociated learning in drug states (state dependent learning). In D. Efron (Ed.), Psychopharmacology. USPHS Publication No. 1836, 1968.

Revusky, S. H. Aversion to sucrose produced by contingent $\mathrm{X}$-irradiation: Temporal and dosage parameters. Journal of Comparative \& Physiological Psychology, 1968, 65, 17-22.

Sinith, J. C., \& Roll, D. L. Trace conditioning with X-rays as an aversive stimulus. Psychonomic Science, 1967, 9, 11-12.

Strouthes, A., \& Naverick, D. Saccharin and $\mathrm{H}_{2} \mathrm{O}$ consumption as a function of $\mathrm{H}_{2} \mathrm{O}$ deprivation. Psychonomic Science, $1967,9,523-524$.

(Received for publication June 29, 1973; revision received September 12, 1973.) 